\section{Controls on exports will defend security, without harming labs}

SIR - Your News story "Academics stress licence threat to US science" (Nature 435, $4 ; 2005)$ usefully focuses attention on US export-control regulations and their application to scientific research. But it repeats a common misperception regarding the scope of the export-control regulations in the context of domestic academic laboratories.

The News story states that a licence is required for certain foreign nationals to operate controlled equipment. This is not the case. A foreign national may work with controlled equipment, so long as no controlled technology is released to the foreign national in the process. The controls apply to the release of technology, not to the use of equipment.

The News story also states that the controls apply to technologies relating to a wide range of equipment. But licences are only required for release of a relatively small subset of technologies to foreign nationals from a limited number of countries. For instance, the article cites lasers as an example, yet no licences would be required to teach a foreign national how to use most lasers.

Finally, US companies and many universities are already complying with these export controls. The president of the University of Maryland, Dan Mote, is quoted as considering that obtaining the required licences could "bring work to a halt" in our nation's laboratories. On the contrary, proper compliance with these rules will strengthen our nation's security while ensuring that American science maintains its pre-eminent research capabilities.

Peter Lichtenbaum

Acting undersecretary for industry and security, US Department of Commerce,

14th Street and Pennsylvania Avenue,

Washington DC 20230, USA

\section{Veracity of raw images can also come into question}

SIR - Your News Feature "CSI: cell biology" (Nature 434, 952-953; 2005) raises questions about the legitimacy of editing images. In this context, I am regularly surprised at the essentially binary appearance of many published fluorescence micros copy images, with the apparent absence of both intermediate intensities and Poisson noise.

This may predate Photoshop and arise at the time of acquisition, when alterations to the offset of photodetectors can be used to suppress low or intermediate signals and the gain setting used to produce detector saturation by the remaining portion of the original signal.

Although attempting to curtail illegitimate manipulation of digital images is very important, it is also relevant to consider the veracity of raw images. A solution would be to require a statement about detector settings in the methods section of publications and, further, to require that original unenhanced digital images, in the proprietary format, which will usually contain details of the microscope settings, are included in online supporting material. Jeremy Adler

Department of Developmental Biology,

The Wenner-Gren Institute,

Stockholm University, S106 91,

Stockholm, Sweden

\section{Academic boycott would damage chances for peace}

\section{SIR - As your News story, "Palestinian} unease sparks fresh calls for Israeli boycott (Nature 434, 813; 2005) notes, intermittent attempts have been made to boycott Israeli academics, in order to protest at the lack of resolution of the Israeli-Arab conflict.

These efforts - such as the recent attempt by some members of the UK Association of University Teachers to impose a boycott of two universities, which was overturned last month (Nature 435, 550; 2005) - are counterproductive in an environment where mistrust is a key obstacle to peace, particularly after four years of escalated violence. This has included closures of Palestinian universities by Israeli forces and direct attacks on Israeli institutions of higher learning, such as the terrorist bombing of the cafeteria at Hebrew University that killed and injured nearly 100 people, mostly students.

In addition to reducing the enmity that must be overcome before peace can be achieved, collaboration between Israeli and Palestinian academics has brought millions of dollars in funding to suburban Jerusalem's Al-Quds University. Joint efforts have enhanced the training and skills of the Palestinian faculty members - skills they and their students will need in any future Palestinian state, if it is to be viable, productive and at peace with its neighbours.

Even at the height of the Cold War, with nuclear missiles aimed at each other's heartlands, the United States and the Soviet Union considered academic exchanges a worthwhile way of enhancing the prospects for peace. Although there are, of course, major differences between the two conflicts, the same principle holds true for Israelis and Palestinians. Only those who are interested in perpetuating this conflict indefinitely stand to gain anything from preventing such exchanges.

John R. Cohn

Thomas Jefferson University, 1015 Chestnut

Street, Philadelphia, Pennsylvania 19107, USA

\section{A boycott could do good in Israel, as in South Africa}

\section{SIR - We find it curious that your News} story ${ }^{~}$ Palestinian unease sparks fresh calls for Israeli boycott ${ }^{\prime \prime}$ (Nature 434, 813; 2005) portrays scientific collaboration between Palestinian and Israeli academic institutions as a "beacon of hope" at a time when Israel's oppression of the Palestinians is ongoing and, in fact, intensifying.

Plain logic would lead us to think that liberation is required first, and then perhaps collaboration, with justice having already been achieved. To suggest that collaboration despite occupation is a sign of hope defies any understanding of conflict, oppression and the struggle for freedom, justice and genuine peace.

In our view, boycott constitutes one of the very few possibilities for Palestinian non-violent resistance to occupation. Boycott as an instrument of civil resistance did not originate in Palestine. It has been effectively used elsewhere, notably in South Africa, and has earned much support from various groups worldwide.

In the case of Palestine-Israel, a moral, if not active, support of the boycott of Israeli academic and cultural institutions is the least that one expects from conscientious academics, scientists and intellectuals worldwide. Would Nature have described the collaboration of blacks and other liberationists in South Africa with the apartheid government and its institutions as a "beacon of hope"?

Rita Giacaman ${ }^{\star}$ Jacqueline Sfeirt, Ismat al-Shakhshirł

*Institute of Community and Public Health, Birzeit University, Birzeit, West Bank, Palestine tDepartment of Education, Bethlehem University, Bethlehem, West Bank, Palestine

†Department of Chemistry, AL-Najah University, Nablus, West Bank, Palestine

The News story in question was describing events and attitudes, not presenting an editorial perspective. For the record, Nature has consistently opposed boycotts, both of South African academics in the time of apartheid and, more recently, of researchers in Israel - Editor, Nature.

Contributions to Correspondence may be submitted to corres@nature.com. They should be no longer than $\mathbf{5 0 0}$ words, and ideally shorter. Published contributions are edited. 